\title{
Analysis of Business Attributes in Information Technology Environments
}

\author{
Hong Joo Lee*
}

\begin{abstract}
Information technology is changing the business value chain and business systems. This situation is due to the business value chain and the value creation factors in business. Technology companies and researchers are developing new businesses, but many companies and researchers cannot find successful ways to analyze and develop a business in a specific way. In this paper, the following will be explored. First, the value creation motive in business is analyzed through a literary review. Second, business attributes are analyzed while considering the value creation motive and business factors in management. Finally, the business attributes of information technology are studied through a review of previous research that has been conducted on this topic.
\end{abstract}

Keywords-Business Attributes, Information Technology, Value Chain, Business System

\section{INTRODUCTION}

Today's researchers on corporations and businesses are presenting information technology (IT) as a factor in the creation of business values in the future and are studying IT and business from the viewpoint of business competitiveness [1,2], business strategy [3], and work effectiveness [4].

A report published by the OECD presents information and communications technology as an essential factor in the creation of business competitiveness and business achievement, and explains IT as a new motive for business growth [5,6]. Lee (2007) also stressed in his study that it is crucial to use IT to create business values [7].

As mentioned, IT, as a key element in the creation of business values, has brought about a change in the economic system and in companies' business value chains, and a great number of companies have recently tended to increase their investments in IT [8, 9, 10, 11, 12,13].

In particular, various types of businesses that capitalize on IT are emerging due to the recent change in business environments and the progress in IT, so a systematic and rational analysis of new businesses is desperately needed. In response, this paper analyzes the business attributes of companies that are required for the emergence of IT as a value-creating factor in today's business environments, for the creation of businesses and their values, and presents such attributes in a fresh way.

\subsection{Research Process}

This paper conducted its research inthe following research process. First, the motives for

Manuscript received March 9, 2011; accepted May 16, 2011.

Corresponding Author: Hong Joo Lee

* Dept. of Industrial \& Management Engineering, Kyonggi University, Suwon, Korea (blue1024@kgu.ac.kr) 


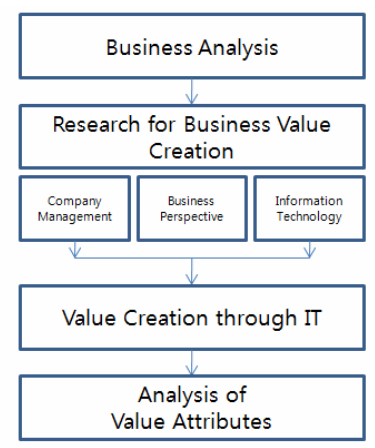

Fig.1. Research process

value creation in the IT environment were analyzed in terms of technology and business, respectively, to analyze business attributes. In addition, the factors of companies' value creation were analyzed through a review of previous research that has been conducted.In other words, the managerial activity factors in the creation of business values were analyzed, and the factors of companies' value creation using IT were studied by analyzing activities that are aimed at creating values in terms of IT and business. Second, the value creation factors using IT were studied by analyzing the findings of previous research. Third, the future business strategies of companies were analyzed, particularly the factors that are studied in companies to create future values; and based on the analyzed results, the attributes of business value creation are presented in this paper.

\section{RELATED WORK}

\subsection{Motives for business value creation}

Karmarkar (2007), in his paper, analyzed the composition ratio of the American Gross Domestic Product (GDP) [14], and found that IT based businesses have recently taken up a large proportion of this GDP.

His paper analyzed that while physically produced products took up a major part of business value creation in the past, IT services are now a major part of business value creation, and motives for this business value creation are based on IT.

The Nomura Research Institute (2002) and Michal Porter (1996) maintained that business values are decided according to what value creation motives work in designing and embodying a model $[15,16]$. In addition, Sung Hyun Chun (2001) asserted in his research that the value creation motives of a business model could be analyzed in large part in terms of the technology and business aspects [8].

In other words, as the enabling technology foundation, which makes new business methods possible turns up, an analysis is made of the manner by which the business opportunities and various enabling effects provided by this technology should be used for value creation. This studies the business value creation factors, which are provided by technology, by analyzing the technology attributes that make new businesses possible. 


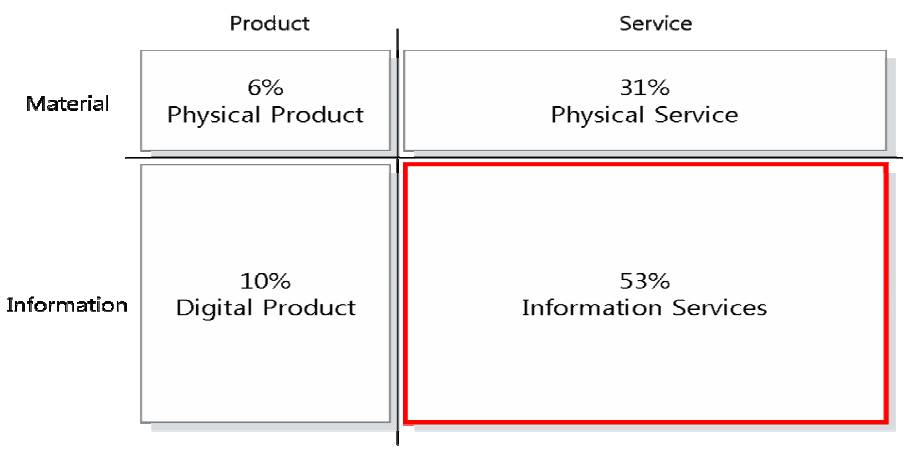

Fig. 2. GDP distribution ratio of the US economy [30]

Table 1. Value creation field of a business model [8]

\begin{tabular}{c|l}
\hline Value Creation Field & \multicolumn{1}{c}{ Definition } \\
\hline Technology aspect & $\begin{array}{l}\text { This is a case wherein the motive for value creation is triggered by technology. In other words, as the } \\
\text { enabling technology foundation that makes new business methods possible turns up, this aspect looks } \\
\text { for a method of using the business opportunities and various enabling effects provided by this tech- } \\
\text { nology for value creation. }\end{array}$ \\
\hline Business aspect & $\begin{array}{l}\text { This is a case wherein the motive for value creation is triggered by various business considerations. } \\
\text { The motive for value creation is brought about by various business motives such as finding out what } \\
\text { kind of business method should be designed. }\end{array}$ \\
\hline
\end{tabular}

\subsection{Business management factors for creating business values}

The research on business value creation conducted nowadays by companies is still at a stage wherein systematic analyses are not yet sufficient and have a limited approach based only on the business experiences of those at a working level. Therefore, a systematic analysis of business value creation is needed.

Cho Dong Sung (2007) explained the business management factors for creating values as strategy, management, and operation.

He analyzed as the essential factors for managing a company the explanation of its aims according to the social role of an organization, the grabbing of an opportunity, and the utilization of the opportunity by optimizing it.

Likert (1967) concluded in his study that the operations and leadership of an effective organization are connected to the achievements of a business [18], and Marcione (1983) studied the productivity of a business after it adds technology innovation ability to its traditional labor productivity. In addition, he presented as the main factors of attaining such productivity a technological production process and an organizational structure [19].

An Woon Suk (2007) presented the fields for creating values in a business as production management, financial management, personnel management, and marketing management [20]. In addition, Bateman (2007) presented in his book the factors needed to improve and manage the achievement of a business goal as strategic planning, organization, achievement management, leadership, and motivation [21]. The study analyzed that rational management decision-making can be implemented via strategic planning and theplanning of the structure of a business, as a 
Table 2. Business management factors for creating values [17]

\begin{tabular}{c|l}
\hline Factor & \multicolumn{1}{c}{ Definition } \\
\hline Strategy & $\begin{array}{l}\text { This is a decision-making activity in which goals are set up according to the social role of an organi- } \\
\text { zation and its goal of taking advantage of a given opportunity in its exterior environments. }\end{array}$ \\
\hline Management & $\begin{array}{l}\text { This is an activity in which the resources that are being used to fulfill a chosen strategy are minimized } \\
\text { or the goals that are being pursued using given resources are maximized. }\end{array}$ \\
\hline Operation & This means that operation activities are literally executed according to fixed methods and systems. \\
\hline
\end{tabular}

component that makes it possible to effectively manage the resources of a business, such as personnel, finance, and information.

In addition, Bateman found that leadership and motivation are the factors that make it possible for a business to grow in a sustainable way. Jones and Jennifer (2008) analyzed in their book that strategic planning, organization, motivation, and achievement management are the four factors that a business needs to maximize its achievements by using its resources to the maximum level [22].

Daft (2009) analyzed the value creation of a business through theeffective management of factors such as management strategy, business structure, and motivation for affairs to reach the highest level of management achievement [23].Haksever (2004) found that the factors needed to create values in a business are the affairs that could improve its values indirectly, which he called, "non-financial factors." That is, he found that the time-related factors of value creation in business are quality improvement, which is a long-known factor; strategic development, human

Table 3. Business value creation factors [24]

\begin{tabular}{c|l}
\hline Value Scope & \multicolumn{1}{c}{ Value Creation Activities } \\
\hline Financial factors & Profit from selling products, profit creation activities, stocks \\
\hline Non-financial factors & $\begin{array}{l}\text { Love for company, social reputation level, autonomy, continuous profit creation } \\
\text { methods }\end{array}$ \\
\hline Time & $\begin{array}{l}\text { Strategic investments in products, future technology, quality control, human re- } \\
\text { sources, long-term management strategy }\end{array}$ \\
\hline
\end{tabular}

Table 4. Analysis of company business value factors

\begin{tabular}{|c|c|c|c|c|c|c|c|c|}
\hline & $\begin{array}{c}\text { Cho } \\
(2007)\end{array}$ & $\underset{(2007)}{\mathrm{An}}$ & $\begin{array}{l}\text { Likert } \\
(1967)\end{array}$ & $\begin{array}{l}\text { English \& } \\
\text { Marcione } \\
\text { (1983) }\end{array}$ & $\underset{(2007)}{\text { Bateman }}$ & $\begin{array}{c}\text { Jones \& } \\
\text { Jennifer } \\
(2008)\end{array}$ & $\begin{array}{c}\text { Daft } \\
(2009)\end{array}$ & $\begin{array}{c}\text { Haksever } \\
(2004)\end{array}$ \\
\hline Leadership & & & $\sqrt{ }$ & & $\sqrt{ }$ & & & \\
\hline $\begin{array}{l}\text { Organization } \\
\text { Management }\end{array}$ & & & $\sqrt{ }$ & $\sqrt{ }$ & $\sqrt{ }$ & & $\sqrt{ }$ & \\
\hline $\begin{array}{c}\text { Strategy } \\
\text { (Management } \\
\text { \& Research } \\
\text { Developing) }\end{array}$ & $\sqrt{ }$ & & & & $\sqrt{ }$ & $\sqrt{ }$ & $\sqrt{ }$ & $\sqrt{ }$ \\
\hline Operation & $\sqrt{ }$ & & & & & & & \\
\hline $\begin{array}{c}\text { Management } \\
\text { (Production, } \\
\text { Financial, HR) }\end{array}$ & $\sqrt{ }$ & $\sqrt{ }$ & & $\sqrt{ }$ & $\sqrt{ }$ & $\sqrt{ }$ & & $\sqrt{ }$ \\
\hline Marketing & & $\sqrt{ }$ & & & & & & $\sqrt{ }$ \\
\hline Motivation & & & & & $\sqrt{ }$ & $\sqrt{ }$ & $\sqrt{ }$ & \\
\hline
\end{tabular}


resources, and long-term management strategy [24].

As mentioned, research on the factors of business value creation and their attributes was conducted from various aspects, and the findings from previous research are presented in Table 4.

\subsection{Value creation with technology}

This chapter analyzes, based on previous research, why many researchers emphasize the role and importance of technology in creating business values.

Hiroyuki and Tsuyoshi (1992) pointedtechnology outas the most fundamental factor of a company's essential capacities [25]. Theydefined it as the indispensable factor in a company's decision-making and strategy implementation. Saul and Jeff (2006) clearly stated that a technology-oriented business strategy is needed to realize business achievements, and that technology is an essential element of the implementation of a business strategy [26]. Schumpeter (1939) also presented the five factors of capital growth, population growth, market change, technology change, and production organization changeas motives that are capable of changing an economic system, and he defined technology and production organization changes as the main factors of innovation [27]. Heinrich (2003) insisted that an innovative change in technology will lead to the restructuring of the competitivelandscape in the industry, andhe presented the changes caused by technology from the aspects of technology development, capacity for customer relationships, attributes of products, value chain, value creation, and product achievements, based on documentary examinations [28]. In addition, Kim Change Tae (2001) insisted that information is exchanged between producers and consumers until value is delivered from producers to consumers through the value chain, and that IT can change the way business values flow [10]. Seth and Claes (2005) presented a change in the value chain due to progress in IT and the achievements thatit drove [13]. Lancioni (2000) maintained in his research that Internet relatedmakes business management in a company more effective. This was based on analyzing the findings of previous research conducted by researcherslike Rayport and Sviokla (1995) and Shapiro and Varian (1999) [11,12,29]. Leem (2002) defined IT as a crucial element of the improvement and maintenance of a company's competitiveness [30], and Hitt and Brynjolfsson (1996) analyzed that IT provides customers with added value and that it has a positive effect on a company's productivity [31]. Tushnab and Anderson (1986) studied the effects of technology from the viewpoint of products and processes and maintained that as a result of technology change; products are improved, new products emerge, processes change, and innovation occurs, all ofwhich will lead to improved achievements in the industry [32]. Margaret and Garry (2003) studied how technology has brought about a change in the value creation process and the value delivery system, which has made companies more effective and has made possible their achievements in delivering customer value [33]. Chun Sung Hyun (2001) classified the motives for the value creation of a business model in the new economy based on IT in regards to the technology aspect and the business aspect, and found that technological value creation motives are triggered by technology [8]. In addition, he explained the business factors provided by technology in business environments as being both linking and transforming. Robert (2006) studied the relationship between technology and the value chain by maintaining change phenomena such as the dissolution of the value chain and the shortening of the product life cycle as changes in business environments due to technology [34]. Christensen (2000) classified technology into sustaining technology and disruptive technology and maintained that disruptive technology 
Table 5. Definition of business value creation scope based on technology

\begin{tabular}{c|l}
\hline Value Creation Scope & \multicolumn{1}{c}{ Definition } \\
\hline $\begin{array}{c}\text { Technology changes } \\
\text { business values }\end{array}$ & A change in the type and shape of values that a business provides its customers \\
\hline $\begin{array}{c}\text { Technology changes value } \\
\text { sources }\end{array}$ & A change in the input factors needed for a business to create values \\
\hline $\begin{array}{c}\text { Technology changes the } \\
\text { delivery system }\end{array}$ & $\begin{array}{l}\text { A change in delivery factors that reflect values such as with respect to the prod- } \\
\text { uct, service, and information }\end{array}$ \\
\hline $\begin{array}{c}\text { Technology changes the } \\
\text { value chain }\end{array}$ & $\begin{array}{l}\text { A complete change in the value chain, including the process and distribution sys- } \\
\text { tem of a business }\end{array}$ \\
\hline
\end{tabular}

Table 6. Business value creation with technology

\begin{tabular}{l|c|c|c|c}
\hline \multicolumn{1}{c|}{ Researcher } & $\begin{array}{c}\text { Technology } \\
\text { changes } \\
\text { business values }\end{array}$ & $\begin{array}{c}\text { Technology } \\
\text { changes value } \\
\text { sources }\end{array}$ & $\begin{array}{c}\text { Technology } \\
\text { changes the } \\
\text { delivery system }\end{array}$ & $\begin{array}{c}\text { Technology } \\
\text { changes the } \\
\text { delivery system }\end{array}$ \\
\hline Kim(2001) & O & & & O \\
\hline Cheon (2001) & O & O & O & O \\
\hline Christensen (2000) & O & O & & O \\
\hline Heinrich (2003) & O & & & O \\
\hline Hitt and Brynjolfsson(1996) & O & & & O \\
\hline Lancioni(2000) & O & & & O \\
\hline Margaret and Garry(2003) & O & O & & O \\
\hline Robert (2006) & O & O & & O \\
\hline Saul and Jeff (2006) & O & O & & O \\
\hline Schumpeter (1939) & O & & & \\
\hline Seth and Claes(2005) & & & & \\
\hline
\end{tabular}

could neutralize existing technologies and barriers to market entry by changing customer values on the basis of new functions and attributes [35]. Levitt (1960) said the emergence of new technologies makes it possible to create new values and simultaneously improve customer values and replace existing technology-based products [36]. Therefore, this paper consolidates the results of business value creation with technology by investigating previous research, as shown in Tables 5 and 6.

\subsection{Research on business value creation with technology}

According to previous research on business value creation, a research on company strategies is presented as a major research approach in the analyzing and drawing up of business values in the future. In particular, this kind of research has been steadily emphasized since the 1960s, when the importance of a strategy aimed at creating business value began to be discussed fully.

Anthony (1965) maintained that a company needs strategic planning to clarify its relationship with its environment, due to the accelerated changes in business environments such as technology innovation, entry into slow-growing economies, intensified competition among companies, and the internationalized development of business activities [37]. Schendel and Hofer (1978) stressed the importance of strategy as an essential idea that a company should possess as it 
changes its perception of its rivals and as its organization becomes more complex [38]. In particular, the analysis of other business management factors such as technology, markets, and environments should be conducted in advance to create business values nowadays, and a great number of researchers have studied and maintained the necessity of the connection between strategy and technology in a company to create business values to the maximum level $[39,40,41,42,43]$. In addition, Suresh and Paul (2000) insisted from their substantial research that technology and strategy should be interconnected [44].

Researches on companies' resource management for business value creation have been conducted in various areas by various researchers. This paper pointed out resource management as a business value creation factor based on the Business Resources Theory [45], in which the internal environments and resources of a company are presented as a business value creation factor. In detail, previous researches related to business value creation were classified in this paper into organization, finance, and operations researches. In addition, "organization management" means the management of the tangible and intangible resources of a company, including its human resources [46, 47], and "finance" means the flow of liquid funds such as profit from selling products and shares [24].

Cho Dong Sung (2007) also defined operation as a management activity according to previously fixed methods and systems, and defined strategy along with management as a business value creation factor [17].

In addition, he analyzed market-oriented business-implementing companies as achieving more $[7,48,49,50]$. In particular, Hanne and Bjarne (2004), after analyzing previous bodies of researchon business value creation from the market viewpoint, said that the market analysis scope includes consumers, customers, and rivals [51].

Moreover, many researchers, including Hiroyuki and Tsuyoshi (1992) and Saul and Jeff (2006), defined technology as an essential capacity of a company and as beingan essential factor of a company's implementation of its strategy in the process of creating business values $[25,26]$.

In addition, researches on the current value factors of a company and its future value creation that takes such factors into account are being actively conducted. Aaker (2007) found that a company should set up a management strategy if it wants to create new businesses [52], and insisted that the company should analyze its internal and external environments to establish an effective strategy for value creation.

Lynch (2006) maintained that a company should analyze its customers in setting up a strategy for creating business values [53], and Grant (1995) maintained that a company should analyze its industry's internal and external environments [54].

Hooley and Saunders (1993) insisted that a company that is establishing a strategy must analyze its industrial environments and business environments [55]. Brown and McDonald (1994) conducted a research to analyze the formulation of future business strategies through an analysis of present business and industry environments and technologies, by conducting a research on the process of establishing a competitive strategy [56].

Lee (2006) also presented in his paper the model shown in Figure 4 of an analysis method for creating new business values, which he came up with by conducting a research on business value factors such as the present internal and external business environments of a company, its strategy, and its analysis of its customers [57].

In other words, Lee concluded that business values can be successfully determined by considering the company strategy according to the company's internal and external environments, cus- 


\begin{tabular}{|c||c|c|}
\hline \multicolumn{1}{|c|}{ As-Is } & \multicolumn{1}{c|}{ To-Be } \\
\hline Environment & $\begin{array}{c}\text { Analysis in } \\
\text { External/Internal } \\
\text { /nformation Tech }\end{array}$ \\
\hline Customer & Customer Satisfaction Facts & $\begin{array}{l}\text { Technology Needs/ } \\
\text { Company Strategy }\end{array}$ \\
\hline
\end{tabular}

Fig. 3. Analysis model for determining business value factors [57]

tomer satisfaction factors, resources, technological elements, and market environments, based on the company's present and future situations.

\section{CONCLUSION}

With the recent emergence of various company models due to IT progress; bodies of research are being conducted in companies to analyze businesses more effectively andto develop a better business model. In response, today's company and business researchers are using IT as the basis for research on the competitiveness of an industry or a business, company strategies, and work effectiveness. Similar to this, IT, which is an essential factor in the creation of business values, has brought about changes in companies' value chains, the economic system, and input factors for creating values in business environments.

In response, this paper analyzed the business value creation motives of companies by reviewing previous works of research. The results of the literary review revealed that business value creation motives could be divided into the business aspect and the technology aspect. It was found that business value creation motives are triggered by full business considerations as motives for creating values, and that technology-based value creation motives are triggered by technology as a motive for creating values. Thus, value creation was analyzed in terms of business management activities, business management fields, achievement-deciding factors, and value creation factors. This was done from the viewpoint of business management and businesses, through the results of the analysis of each area based on these business researches. In addition, technology was presented as the most fundamental factor of a company's essential capabilities, and changes in the value chain caused by progress in IT and its production of achievements were analyzed by reviewing previous researches in which technology was studied as an essential element of companies' strategy formulation and implementation.

Likewise, the research was conducted by classifying the previous researches that werementioned earlier, into the technology aspect and the business aspect, through which the five business value creation factors were analyzed. The findings are as follows: first, strategy is the indispensable field for creating values in a company in IT environments. In other words, strategy was presented as a major research method for analyzing and determining future business values. Second, resource management is crucial for a company to effectively produce and manage goods by using resources, a fundamental basis for creating its values. In addition, resource management plays a pivotal role in creating business values by increasing effectiveness through management of the company's personnel and organizations.

Third, through the analysis of markets, marketing elements can be analyzed, through which 
Hong Joo Lee

Table 7. Analysis of business value creation factors

\begin{tabular}{|c|c|c|c|c|c|c|c|}
\hline \multirow{2}{*}{ Researcher } & \multirow{2}{*}{ Strategy } & \multicolumn{3}{|c|}{ Resource Management } & \multirow{2}{*}{ Market } & \multirow{2}{*}{ Tech } & \multirow{2}{*}{$\begin{array}{c}\text { Business } \\
\text { Environmen }\end{array}$} \\
\hline & & Organization & Financial & Operation & & & \\
\hline $\operatorname{Kim}(2001)$ & 0 & 0 & & 0 & & 0 & \\
\hline $\operatorname{Ahn}(2007)$ & 0 & 0 & 0 & 0 & $O$ & & \\
\hline Cheon(2001) & 0 & & & & $O$ & 0 & \\
\hline Cho(2007) & 0 & 0 & & 0 & & & \\
\hline Aaker(2007) & 0 & & & & & & 0 \\
\hline Anthony(1965) & 0 & & & & & & \\
\hline Bateman(2007) & $O$ & 0 & 0 & 0 & & & \\
\hline Boyer et al(1996) & 0 & & & & & 0 & \\
\hline Brown and McDonald(1994) & 0 & & & & & 0 & 0 \\
\hline Christensen(2000) & & & & & & 0 & \\
\hline $\operatorname{Daft}(2009)$ & 0 & 0 & & 0 & & & \\
\hline Dean and Snell(1996) & 0 & & & & & 0 & \\
\hline English and Marcione(1983) & & 0 & & 0 & & & \\
\hline Grant(1995) & 0 & & & & & & 0 \\
\hline Haksever(2004) & 0 & 0 & 0 & 0 & 0 & 0 & \\
\hline Heinrich(2003) & & & & 0 & 0 & $O$ & \\
\hline Hiroyukitami(1992) & $O$ & & & & & 0 & \\
\hline Hitt and Brynjolfsson(1996) & & & & & & 0 & \\
\hline Hooley and Saunders(1993) & $O$ & & & & & & 0 \\
\hline Jones and Jennifer(2008) & $O$ & 0 & 0 & 0 & & & \\
\hline Lee(2006) & 0 & & & & 0 & & 0 \\
\hline Likert(1967) & & $O$ & & 0 & & & \\
\hline $\operatorname{Lynch}(2006)$ & 0 & & & & 0 & & \\
\hline Margaret and Garry(2003) & & & & 0 & 0 & 0 & \\
\hline Melissa A. Schilling(2005) & $O$ & & & & & & \\
\hline Meredith(1987) & 0 & & & & & 0 & \\
\hline Robert(2006) & & & & & & 0 & \\
\hline Saul and Jeff(2006) & $O$ & & & & & 0 & \\
\hline Schendel and Hofer(1978) & 0 & & & & & & \\
\hline Schumpeter(1939) & & 0 & & 0 & 0 & 0 & \\
\hline Skinner(1984) & 0 & & & & & 0 & \\
\hline Suresh and Paul(2000) & 0 & 0 & & 0 & & 0 & \\
\hline Tushnab and, Anderson(1986) & & & & $O$ & & $O$ & \\
\hline Voss(1986) & 0 & & & & & $O$ & \\
\hline
\end{tabular}


business creation factors can be studied. Fourth, today's technology is a crucial motive for creating business values, and a number of companies have carved out new markets and new fields with technology. Therefore, it can be inferred that technology plays an important role in opening new markets and thus, in creating new businesses.

Finally, the environment is the most important element in setting up a strategy. Thus, a proper strategy can be set up only when business environments are analyzed beforehand.

\section{Research Limitations And Future Research SubJects}

This paper analyzed the business factors in IT environments based on documentary bodies of research. For this research to further grow, it should be followed by a substantial research with statistical verifications and real business cases analyses. In conclusion, the business community can make full use of this paper as a basic reference material for developing new businesses in IT environments.

\section{REFERENCE}

[1] Segars A, Grover V., "Strategic group analysis: a meth-odological approach for exploring the industry level impact of information technology". Elsevier journal Omega, Vol.22, Issue 1, January. 1994, 13-34.

[2] Sethi V, King WR. Development of measures to assess the extent to which an information technology application provides competitive advantage. Management Science, Vol.40 Issue 12, December. 1994, 1601-1627.

[3] Mahmood M A. and Siew Khim Soon, "A comprehensive model for measuring the potential impact of information technology on organizational strategic variables”. Decision Sciences, Vol.22, Issue 4, September 1991, 869-897.

[4] G. Torkzadeh, W.J. Doll, "The development of a tool for measuring the perceived impact of information technology on work”, Omega. International Journal of Management Science. Vol.27, Issue 3, June. 1999, 327-339.

[5] OECD, "ICT Diffusion to Business: National Peer Reviews", http://www.oecd. org, 2009.

[6] OECD, "Technology, Trade in Services, and Economic Growth, Catherine L. Mann, OECD”, 2007.

[7] Jaworski B, Kohli AK. "Market orientation: antecedents and consequences", Journal of Marketing, Vol.57, July. 1993, 53-70.

[8] S.J Cheon, "New Business Model, Jipmoondang, 2001.

[9] B. B. M. Shao, W. T. Lin, "Measuring the value of information technology in technical efficiency with stochastic production frontiers", Information and Software Technology, Vol.43, Issue 7, June. 2001, 447-456.

[10] Kim, Chang-Tae, "Enterprise Management according to the Development of Information Technology”, Management Information Systems Review, Vol.6, 2001, 45-61.

[11] Lancioni, R.A., Smith, M.F. and Oliva, T.A., "The role of internet in supply chain management", Industrial Marketing Management, Vol.29, Issue 1, January 2000, 45-56.

[12] Rayport, J.F. and Sviokla, J.J., "Exploiting the virtual value chain", Harvard Business Review, November. 1995, 75-85.

[13] Seth Jonsson and Claes Gunnarsson, "Internet technology to achieve supply chain performance", Business Process Management Journal, Vol.11 Issue 4, 2005, 403-417.

[14] Karmarkar et al, "Operations Management in the Information Economy: Information Products, Processes and Chains", Journal of Operations Management, Vol.25, Issue 2, , March, 2007, 438-453.

[15] Hisao Nakajima, "Marketing Strategy in the era of of Ubiquitous Network", NRI Papers, Issue 44, 
March. 2002.

[16] Michael E. Porter, "What is Strategy?", Harvard Business Review, November . 1996.

[17] D.S Cho, "Management for 21 st", Seoul Economics and Management, 2007.

[18] Likert, R., The Human Organization, McGraw-Hill, 1967.

[19] Jon English, Anthony R. Marcione, "Productivity: A New Perspective", California Management Review Vol.25, Issue 2, Jan. 1983, 57-56.

[20] W.S Ahn, "Marketing Theory and Case", Daejin, 2007.

[21] Thomas S. Bateman, Scott A. Snell, "Management: Leading \& Collaborating in a Competitive World", McGraw-Hill, 2007.

[22] Jennifer M. George, Gareth R. Jones, "Contemporary Management: Creating Value in Organizations", McGraw-Hill, 2008.

[23] Richard L. Daft, "The new era of management”, Thomson South-Western, 2009.

[24] Cengiz Haksever et al, "A Model of Value Creation: Strategic View", Journal of Business Ethics, Kluwer Vol.49, Issue 3, February. 2004, 295-307.

[25] Hiroyuki Itami and Tsuyoshi Numagami, "Dynamic Interaction between Strategy and Technology", Strategic Management Journal, Vol.13, Issue S2, Winter. 1992, 119-135.

[26] Saul J. Berman and Jeff Hagan, "How technology-driven business strategy can spur innovation and growth", Strategy \& Leadership, Vol.34, Issue 2, 2006, 28-34.

[27] Schumpeter, Joseph Alois, "Business cycles: a theoretical, historical and statistical analysis of the capitalist process", McQraw Hill, 1939.

[28] Heinrich M. Arnold, "Technology Shocks", Physica-Verlag, 2003.

[29] Shapiro, C. and Varian, H.R., "Information Rules: A Strategic Guide to the Network Economy", Harvard Business School Press Boston MA, 1999.

[30] Choon Seong Leem, Sang kyun Kim, "Introduction to an integrated methodology for development and implementation of enterprise information systems", Journal of Systems and Software, Vol.60, Issue 3, February. 2002, 249-261.

[31] L.M. Hitt and E. Brynjolfsson, "Productivity, business profitability, and consumer surplus: three different measures of information technology value”, MIS Quarterly, Vol.20 Issue 2, June. 1996, $121-142$

[32] Tushnab ML, Anderson P, "Technological Discontinuities and Organizational Environments", Administrative Science Quarterly, Vol.31, Issue 3, September. 1986, 439-465.

[33] Margaret A. White and Garry D. Bruton, "The Management of Technology and Innovation: A Strategic Approach", THOMSONTM SOUTH-WESTERN, 2003.

[34] Robert M. Verburg at al, "Managing Technology and Innovation", Routledge Taylor \&Francis Group, 2006.

[35] Christensen CM and Tedlow RS, "Patterns of Disruption in Retailing", Harvard Business Review, Issue January/February, 2000, 42-45.

[36] Theodore Levitt, "Marketing Myopia", Harvard Business Review, Vol.38, July-August. 1960, 24-47.

[37] Anthony R, "Planning and Control System: A Framework for Analysis", Harvard University, 1965.

[38] Hofer C. W. and Schendel D., "Strategy formulation: Analytical concepts", MN: West Publishing, 1978.

[39] Boyer, K.K., Ward, P.T., Leong, K.G., "Approaches to the factory of the future: an empirical taxonomy”, Journal of Operations Management, Vol.14, Issue4, November. 1996, 297-313.

[40] Dean, J.W. Jr., Snell, S.A., "The strategic use of integrated manufacturing: an empirical examination". Strategic Management Journal, Vol.17, Issue 6, 1996, 459-480.

[41] Meredith, J.R., "The strategic advantages of new manufacturing technologies for small firms". Strategic Management Journal, Vol.8, Issue 3, May/June 1987, 249-258.

[42] Skinner, W., "Operations technology: blind spot in strategic management, Interfaces, JanuaryFebruary. 1984, 116-125.

[43] Voss, C.A., "Managing new manufacturing technologies, Operations Management Association Monogram", Michigan State University, MI, Issue 1, 1986.

[44] Suresh Kotha and Paul M. Swamidass, "Strategy, Advanced Manufacturing Technology and Per- 
formance: Empirical Evidence from U.S. Manufacturing Firms", Journal of Operations Management, April. 2000, 257-277.

[45] Wernerfelt B., "A Resource-based view of the firm", Strategic Management Journal, vol.5 Issue2, 1984, 171-190.

[46] Dunford, B. B., Snell, S. A. and Wright, P. M. "Human resources and the resource based view of the firm”, Journal of Management, Vol.27 Issue6, 2001, 701-21.

[47] Fiol, M., "Revisiting an identity-based view of sustainable competitive advantage". Journal of Management, Vol.27, Issue 6, 2001, 691-699.

[48] Greenley G. "Forms of market orientation in UK companies". Journal of Management Studies, Vol.32 Issue 1, 1995, 47-66.

[49] Narver JC and Slater SF., "The effect of a market orientation on business profitability", Journal of Marking, October. 1990, 20-35.

[50] Ruekert RW. "Developing a market orientation: an organizational strategy perspective", International Journal of Research in Marketing, Vol.9, Issue 3, August. 1992, 225-245.

[51] Hanne Harmsen and Bjarne Jensen, "Identifying the determinants of value creation in the market: A competence-based approach", Journal of Business Research, Vol 57, No 5; May. 2004, 533-547.

[52] David A. Aaker, "Strategic Market Management", John Wieley \& Sons, 2007.

[53] Richard Lynch, "Corporate Strategy", Prentice Hall, 2006.

[54] Grant, R.M., "Contemporary Strategy Analysis", Blackwell, 1995.

[55] Hooley, G.J. and Saunders, J., "Competitive Positioning: the Key to Market Success", Prentice-Hall, London, 1993.

[56] Brown, L and McDonald, M. "Competitive Marketing Strategy for Europe", Macmillan, 1994.

[57] Hong Joo Lee, "A Study on Development of Business Factors by Mobile Telecommunication Customer Needs Analysis in Ubiquitous Environment", Ph.D Paper The Graduate School, Yonsei University, 2006.

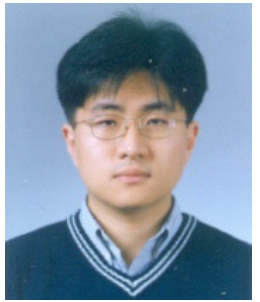

\section{HongJoo Lee}

Hong Joo Lee graduated from the School of Computer Science at Carnegie Mellon University in Pittsburgh, PA, USA. He also received his Ph.D in Industrial Engineering from Yonsei University, Seoul, South Korea. He currently works at Kyonggi University as an assistant professor. His research interests include the strategic use of new technology, business technology, and technology strategy. 